Diabetologia 10, 309-315 (1974)

(C) by Springer-Verlag 1974

\title{
The Autoregulation of Insulin Secretion in the Isolated Pancreatic Islets of Lean (obOb) and Obese-Hyperglycemic (obob) Mice
}

\author{
L. Loreti, J.C. Dunbar, S. Chen and P.P. Foà \\ Department of Research, Sinai Hospital of Detroit, Michigan, USA \\ Received: September 17, 1973, and in revised form: April 1, 1974
}

\begin{abstract}
Summary. The autoregulation of insulin secretion was studied using perifused and incubated pancreatic islets of normal (obOb) mice and of their obese-hyperglycemic (obob) littermates. Islets secreted more insulin when they were perifused than when they were incubated and insulin was allowed to accumulate in the medium. When rat insulin was added to the incubation medium in the concentration of $250 \mathrm{\mu U} / \mathrm{ml}$, the secretory activity of the normal islets was suppressed almost completely. The concentration of exogenous insulin required to inhibit the islets of obese mice was higher and increased with the age of the animals, until it reached a value that was 20 to 30 times greater than that found in the circulating blood. Similar concentrations may well exist in
\end{abstract}

the extracellular fluid of the pancreatic islets. It is possible that while insulin resistance of the peripheral tissues may be responsible for the hyperglycemia of the obob mice, the progressive loss of insulin sensitivity of their pancreatic islets and, consequently, of the normal autoregulation of insulin secretion, may play a role in the progressive hyperinsulinism and, hence, of the obesity characteristic of these animals.

Key words: Feedback control, hyperglycemia, hyperinsulinism, insulin, insulin resistance, mouse insulin, mouse-rat-pork insulin crossreactivity, obese-hyperglycemic syndrome, obesity, pancreatic islets, rat insulin.
The concept that insulin inhibits its own secretion, based on direct and indirect evidence [1-8], provides a possible explanation not only for the reactive hyperglycemia and temporary glucose intolerance frequently observed in the wake of insulin overdosage [9], or of endogenous hyperinsulinism [4, 10], but also for the reverse phenomenon; that is, for the marked degranulation $[11,12]$ and increased insulinogenic activity of pancreatic islets, incubated in the presence of antiinsulin serum (AIS) [13], or isolated from animals that had been treated with ATS [14]. In the intact animal, the apparent inhibition of the $\mathbf{B}$ cells could be the result of hyperinsulinism or of the hypoglycemia that it causes. However, most experiments with incubated or perfused pancreatic tissue, where the two variables can be controlled separately, have indicated that, whatever hypoglycemia may do, hyperinsulinism can inhibit insulin secretion. There have been a few exceptions [15-17]; among them was the observation that fish (bonito) insulin, which suppresses the pancreas of man [18], fails to suppress that of dogs and rats $[15,16]$. We are inclined to attribute this failure to species specificity for, just as fish insulin is not bound by some mammalian anti-insulin sera, so it may not be recognized by the hypothetical insulin receptors on the mammalian $B$ cell. In order to avoid this pitfall and the possible difficulties that mixing insulins with different immunologic characteristics may create in the assay system, we carried out our experiments with mouse islets and rat insulin. The use of islets isolated from normal mice and from their obeselittermates gave us also the means to explore a second proposition; namely, that the hyperinsulinism observed in these animals may be due to failure of the $B$ cells to sense the accumulation of their own product. Preliminary experiments carried out in this laboratory [19] have demonstrated that bovine insulin inhibits the secretion of insulin by the isolated islets of 4 to 5 week old obob mice. However, in these animals, obesity, although recognizable [20], had not yet fully developed and the serum insulin level was only slightly elevated, if at all.

Portions of this paper have been published in abstract form $[21,22]$.

\section{Materials and Methods}

C57-BL-6J mice of both sexes, between 6 and about 44 weeks of age, were obtained from the Jackson Memorial Laboratories, Bar Harbor, Maine, or from our colony of the same strain. For each experiment, 4 obese (obob) and 6 lean (obOb) mice of the same age and, wherever possible, the same litter, were sacrificed under pentobarbital anesthesia $(30 \mathrm{mg} / \mathrm{kg}$, intraperitoneally), after $24 \mathrm{~h}$ of fasting. Their pancreata were removed, without expanding them [23], rinsed in Hanks-Wallace buffer [24], minced with scissors, appropriately pooled, transferred into $15 \mathrm{ml}$ of the same buffer containing approximately $50 \mathrm{mg}$ of collagenase (crude collagenase; $137 \mathrm{U} / \mathrm{mg}$ ) (Worthington Biochemical Corp., Freehold, N.J., U.S.A.) and partially digested by stirring for about $15 \mathrm{~min}$ at $37^{\circ} \mathrm{C}$. After this procedure, the islets were carefully separated from all remaining exocrine tissue by microdissection, with the aid of a binocular microscope [25] and placed into a collection flask containing Hanks-Wallace buffer. The 
width of the islets was measured in 2 orthogonal directions using a micrometer eyepiece. For the purpose of incubation, islets were removed from the collection flask by allowing them to enter into a thin pipette by capillary action, sometimes aided with minimal suction, and were transferred alternately, one at a time, to an experimental and to a control flask. These contained Krebs-Ringer bicarbonate buffer $(10 \mathrm{ml})$, glueose (3 $\mathrm{mg} / \mathrm{ml}$ ), crystalline bovine serum albumin, factor $\mathrm{V}$ (1 g/100 ml) (Nutritional Biochemical Corp., Cleveland, Ohio, U.S.A.; checked for purity by agar gel electrophoresis and by Sephadex G50 column chromatography) and, when indicated, various amounts of rat insulin (Gift of Dr. J. Schlichtkrull, Novo Research Institute, Copenhagen; free of proinsulin, with a glucagon content of $20 \mathrm{pg} / \mathrm{mU}$ and a potency of $24 \mathrm{U} / \mathrm{mg}$ ). The flasks containing 15 islets each, were placed in a Dubnoff metabolic incubator, shaking at the rate of $66 \mathrm{cycles} / \mathrm{min}$, in an atmosphere of $\mathrm{O}_{2}(95 \%)$ and $\mathrm{CO}_{2}$ $(5 \%)$, at $37^{\circ} \mathrm{C}$. After 60,90 and 120 min of ineubation, $100 \mu \mathrm{l}$ aliquots of the medium were removed by means of a microsyringe. Although pancreatic islets could not be easily aspirated through the thin needle of the syringe, we made sure that this had not happened by direct microscopic examination of each aliquot. In other experiments 15 to 20 islets, isolated as described above, were perifused with Krebs-Ringer bicarbonate buffer containing bovine serum albumin $(0.5 \mathrm{~g} / 100 \mathrm{ml})$ and glucose $(3.0 \mathrm{mg} / \mathrm{ml})$, flowing at the rate $0.8-$ $1.0 \mathrm{ml} / \mathrm{min}$ [25]. The effluent was collected in graduated tubes. The insulin content of the samples was measured in duplicate [26] after a dilution estimated to bring its concentration to less than $200 \mu \mathrm{U} / \mathrm{ml}$. The assay was carried out using a guinea pig anti-pork insulin serum (GPAIS), with a binding capacity of $1.36 \mathrm{U} / \mathrm{ml}$ (Lot 550; Gift of Dr. P.H. Wright, University of Indiana, Indianapolis, Indiana, U.S.A.). Pork insulin (Lot PJ$5682 ; 23.9 \mathrm{U} / \mathrm{mg}$; Gift of Dr. M. A. Root, Lilly Research Laboratory, Indianapolis, Indiana, U.S.A.) was used for the preparation of the standards and of the labelled compound. After iodination with ${ }^{131} \mathrm{I}$ (Cambridge Nuclear Radiopharmacentical Co., Billerica, Mass., U.S.A.) [27] and purification [28], the labelled insulin had a specific activity of about $400 \mathrm{mCi} / \mathrm{mg}$, an electrophoretic purity greater than $99 \%$ and provided each assay tube with not less than $20000 \mathrm{cpm}$. Counts were carried out for $3 \mathrm{~min}$. Under the conditions described above, $5 \mu \mathrm{U}$ of insulin could be measured reliably with an error of about $5 \%$. Crude acid-alcohol extracts of mouse pancreas, assayed as stated above, served as the source of mouse insulin and when mixed with rat insulin, were used to determine their cross-reactivity with GPAIS in our assay system. The coefficients of regression were calculated as suggested by Snedecor and Cochran [29], using the data obtained between 30 and $120 \mathrm{~min}$ of incubation. This was considered an appropriate method for determining the statistical significance of the differences between the results obtained in different experiments. In the equation $Y$ has the dimensions of $\mu \mathrm{U} / \mathrm{ml}, \mathrm{X}$ represents $\mu \mathrm{U} / \mathrm{ml} / \mathrm{min}$. It should be pointed out that the intersects on the $\mathrm{Y}$ axis are extrapolated values, not actual measurements and therefore do not provide meaningful information about the amount of insulin known to be released during the isolation procedure [30]. The glucagon content of rat insulin was measured with a method described previously [31].

\section{Results}

Fig. 1 shows the regression lines obtained when we assayed standard solutions of mouse, rat and pork insulin. The reader will note that, as expected [33], our pork-insulin system was more suitable for the assay of pork insulin than for the assay of mouse or rat insulin. However, the lines obtained with mouse and with rat insulin had almost identical regression coefficients. In-

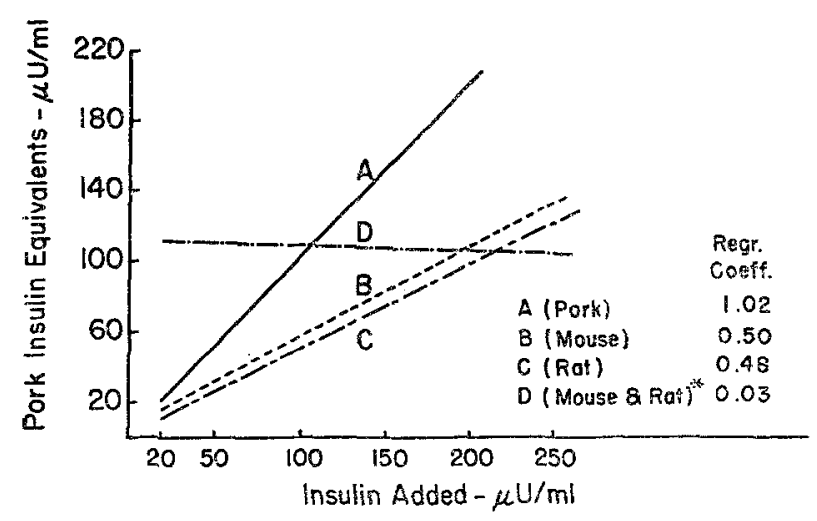

* Rał and mouse insulin added in reciprocoliy inverse proportions. Each point represents a total concentration of $250 \mu \mathrm{U} / \mathrm{ml}$.

Fig. 1. Cross-reactivity of pork, mouse, and rat insulin with guinea pig anti-pork insulin serum

deed, when we mixed mouse and rat insulins, in reciprocally inverse proportions, but constant total amount, we obtained a line that was practically horizontal. Although previous experiments had demonstrated that, under our experimental conditions, no significant amounts of insulin were lost through proteolytic destruction or adsorption to glass [9], Mr. William McLaughlin, in our laboratory, measured the insulin content of incubation media that were allowed to stand at $37^{\circ} \mathrm{C}$, with and without the addition of an inhibitor of proteolytic enzymes (Trasylol; FBA Pharmaceuticals Inc., New York, N.Y., U.S.A.; 2000 KIU/ $\mathrm{ml}$ ), for as long as $2 \mathrm{~h}$ after removal of the islets. There were no significant changes. These experiments gave us confidence that we could measure endogenous mouse insulin in the presence of added rat insulin, accurately and without significant loss of either.

The data given in Table 1 show that obesity, hyperglycemia, hyperinsulinemia and islet hyperplasia were clearly detectable when the obob mice were 6 to 
Table 1. Body weight, concentration of serum glucose and of immunoreactive insulin (IRI) and diameter of the pancreatic islets of normal and obese mice at different ages. Ave. \pm S. $E$. Number of observations in parentheses. The animals were

\begin{tabular}{|c|c|c|c|c|c|}
\hline & $\begin{array}{l}\text { Age } \\
\text { weeks }\end{array}$ & $\begin{array}{l}\text { Body Wt } \\
\text { g }\end{array}$ & $\begin{array}{l}\text { Serum } \\
\text { glucose } \\
\mathrm{mg} / 100 \mathrm{ml}\end{array}$ & $\begin{array}{l}\text { Serum } \\
\text { IRI } \\
\mu \mathrm{u} / \mathrm{ml}\end{array}$ & $\begin{array}{l}\text { Islet } \\
\text { diameter } \\
\mu\end{array}$ \\
\hline Normal mice & $26-30$ & $\begin{array}{l}23.3 \pm 1.8 \\
(19)\end{array}$ & $\begin{array}{l}97.4 \pm 7.9 \\
(19)\end{array}$ & $\begin{array}{l}31.4 \pm 4.9 \\
(7)\end{array}$ & $\begin{array}{l}194.1 \pm 1.4 \\
(902)\end{array}$ \\
\hline \multirow[t]{3}{*}{ Obese mice } & $6-9$ & $\begin{array}{l}47.1 \pm 0.9 \\
(24)\end{array}$ & $\begin{array}{l}136.9 \pm 8.0^{a} \\
(24)\end{array}$ & $\underset{(24)}{54.9}=8.0$ & $\begin{array}{l}214.3 \pm 2.8^{a} \\
(420)\end{array}$ \\
\hline & $12-16$ & $\begin{array}{l}54.4 \pm 1.4 \\
(15)\end{array}$ & $\begin{array}{l}163.2 \pm 11.9^{\mathrm{a}} \\
(14)\end{array}$ & ${ }_{(14)}^{86.2 \pm 13.2^{\mathrm{ca}}}$ & $\begin{array}{l}300.4 \pm 3.4^{d} \\
(584)\end{array}$ \\
\hline & $>32$ & $\begin{array}{l}62.6 \pm 2.3 \\
(7)\end{array}$ & $\begin{array}{l}175.1 \pm 21.5^{\mathrm{a}} \\
(7)\end{array}$ & $\begin{array}{l}134.9 \pm 28.3^{\mathrm{ba}} \\
(7)\end{array}$ & $\begin{array}{l}336.4 \pm 7.4 \mathrm{e} \\
(195)\end{array}$ \\
\hline
\end{tabular}

a $p<0.01$ vs normal mice

b $p<0.01$ vs obese mice $6-9$ Weeks old

c $p<0.05$ vs obese mice $6-9$ Weeks Old

d $p<0.01$ vs obese mice $6-9$ Weeks Old

e $p<0.01$ vs obese mice $12-16$ Weeks Old

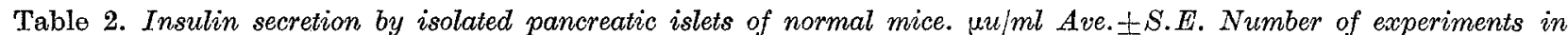
parentheses

\begin{tabular}{|c|c|c|c|c|c|c|}
\hline $\begin{array}{l}\text { Experimental } \\
\text { condition }\end{array}$ & $\begin{array}{l}\text { Rat insulin } \\
\text { added } \\
\mathrm{mu} / \mathrm{ml}\end{array}$ & $30^{\prime}$ & $60^{\prime}$ & $90^{\prime}$ & $120^{\prime}$ & Regression lines \\
\hline $\begin{array}{l}1 . \\
\text { Normal mice } \\
\text { (obOb) (perifusion) }\end{array}$ & 0 & $\begin{array}{l}239.3 \pm 15.9 \\
(9)\end{array}$ & $\begin{array}{l}418.5 \pm 53.4 \\
(8)\end{array}$ & $\begin{array}{l}519.6 \pm 49.4 \\
(8)\end{array}$ & $\begin{array}{l}852.0 \pm 103.9 \\
(8)\end{array}$ & $Y=22.9+6.46 X$ \\
\hline $\begin{array}{l}2 . \\
\text { Normal mice } \\
\text { (incubation) }\end{array}$ & 0 & $\begin{array}{l}68.6 \pm 15.5 \\
(7)\end{array}$ & $\begin{array}{l}91.0 \pm 22.7 \\
(10)\end{array}$ & $\begin{array}{l}137.3 \pm 30.8 \\
(10)\end{array}$ & $\begin{array}{l}154.7 \pm 52.4 \\
(9)\end{array}$ & $Y=36.7+1.01 \mathrm{X}^{\mathrm{a}}$ \\
\hline $\begin{array}{l}3 . \\
\text { Normal mice } \\
\text { (incubation) }\end{array}$ & 0.25 & ${ }_{(9)}^{17.1 \pm 11.5}$ & $\begin{array}{l}33.7 \pm 14.4 \\
(11)\end{array}$ & $\begin{array}{l}44.7 \pm 16.4 \\
(11)\end{array}$ & $\begin{array}{l}45.7 \pm 17.9 \\
(10)\end{array}$ & $Y=11.1+0.32 X^{b a}$ \\
\hline
\end{tabular}

a $p<0.01$ vs Group 1

b 0.01 vs Group 2

Table 3. Insulin secretion by isolated pancreatic islets of obese (obob) mice. $\mu u / m l . A v e . \pm S$. E. Number of experiments in parentheses

\begin{tabular}{|c|c|c|c|c|c|c|}
\hline $\begin{array}{l}\text { Age and } \\
\text { experimental } \\
\text { condition }\end{array}$ & $\begin{array}{l}\text { Rat insulin } \\
\text { added } \\
\mathrm{mU} / \mathrm{ml}\end{array}$ & $30^{\prime}$ & $60^{\prime}$ & $90^{\prime}$ & $120^{\prime}$ & Regression lines \\
\hline $\begin{array}{l}1 . \\
6-9 \text { Weeks } \\
\text { Perifusion }\end{array}$ & 0 & $\begin{array}{l}133.3 \pm 45.7 \\
(5)\end{array}$ & $\begin{array}{l}269.2 \pm 64.1 \\
(5)\end{array}$ & $\begin{array}{l}520.0 \pm 162.4 \\
(4)\end{array}$ & $\begin{array}{l}649 \pm 167.3 \\
(4)\end{array}$ & $\mathrm{Y}=57.3+6.0 \mathrm{X}$ \\
\hline $\begin{array}{l}2 . \\
6-9 \text { Weeks } \\
\text { Incubation }\end{array}$ & 0 & $\begin{array}{l}70.0 \pm 34.0 \\
(2)\end{array}$ & $\begin{array}{l}124.8 \pm 14.6 \\
(5)\end{array}$ & $\begin{array}{l}210.4 \pm 18.6 \\
(5)\end{array}$ & $\begin{array}{l}248.2 \pm 11.4 \\
(5)\end{array}$ & $\mathbf{Y}=8.3+2.06 \mathrm{X}^{\mathrm{a}}$ \\
\hline $\begin{array}{l}3 . \\
6-9 \text { Weeks } \\
\text { Incubation } \\
4 .\end{array}$ & 1 & $(6)^{1.66 \pm 1.66}$ & $(5)^{1.66 \pm 1.66}$ & $(5)^{1.66 \pm} 1.66$ & $(5)^{1.66 \pm} 1.66$ & \\
\hline $\begin{array}{l}6-9 \text { Weeks } \\
\text { Incubation } \\
5 .\end{array}$ & $\mathbf{3}$ & $\frac{15.0 \pm 10.0}{(5)}$ & $\frac{10.0 \pm 10.0}{(5)}$ & $\frac{12.5 \pm 12.5}{(6)}$ & $(6)^{8.3 \pm} 8.3$ & $\mathrm{Y}=15.8-0.05 \mathrm{X}^{\mathrm{ba}}$ \\
\hline $\begin{array}{l}6-9 \text { Weeks } \\
\text { Incubation }\end{array}$ & $\tilde{5}$ & $\begin{array}{l}0 \\
(4)\end{array}$ & $\begin{array}{l}0 \\
(4)\end{array}$ & $\begin{array}{l}0 \\
(4)\end{array}$ & $\begin{array}{l}0 \\
(4) \\
\end{array}$ & \\
\hline
\end{tabular}

${ }^{\mathrm{a}} p<0.01$ vs Group 1

b $p<0.01$ vs Group 2 
9 weeks old and that the diameter of the islets and the serum insulin level continued to increase as the animals grew older. Table 2 shows that islets of normal mice (obOb) continued to secrete insulin throughout the experiment, that the rate of secretion was faster when the islets were perifused in an open system than when they were incubated and that, as the experiment progressed, it decreased as if inhibited by the insulin accumulation in the modium. A still greater inhibition was noted when rat insulin was added to the incubation medium. Since the age of the lean mice did not alter the performance of their islets, all data were pooled. Table 3 shows that the islets of younger obese mice produced about the same amount of insulin as those of their lean littermates, when perifused, but significantly more when incubated $(p<0.01)$. Table 3 shows also

\section{Discussion}

Hyperinsulinism, hyperphagia, obesity and glucose intolerance, with or without fasting hyperglycemia, are common occurrences in patients with adult onset diabetes, in obese individuals [34-38] and in a variety of experimental animals, including the obob mouse used in our study [39-41]. Although these phenomena may well form a vicious cycle, often the primary lesion cannot be identified. It could be insulin resistance of the peripheral tissues $[20,39]$, a malfunction of the hypothalamus $[39,42]$, or a genetically determined tendency to synthesize and to store fat (43, see Fig. 2). Whatever scheme one chooses, primary or secondary insulin resistance, shared in various degrees by the hypothalamus, the skeletal muscle and the adipose

Table 4. Insulin secretion by isolated pancreatic islets of obese (obob) mice. $\mu u / m l$. Ave.土S. E. Number of experiments in parentheses

\begin{tabular}{|c|c|c|c|c|c|c|}
\hline $\begin{array}{l}\text { Age and } \\
\text { experimental } \\
\text { condition }\end{array}$ & $\begin{array}{l}\text { Rat insulin } \\
\text { added } \\
\mathrm{mU} / \mathrm{ml}\end{array}$ & $30^{\prime}$ & $60^{\prime}$ & $90^{\prime}$ & $120^{\prime}$ & Regression lines \\
\hline $\begin{array}{l}1 . \\
>12 \text { Weeks } \\
\text { Perifusion }\end{array}$ & 0 & $\begin{array}{l}577.0 \pm 80.9 \\
(6)\end{array}$ & $\begin{array}{c}812.6 \pm 103.0 \\
(6)\end{array}$ & $\begin{array}{l}1025.3 \pm 132.7 \\
(6)\end{array}$ & $\begin{array}{l}1377.3 \pm 137.2 \\
(6)\end{array}$ & $\mathrm{Y}=294.8+8.71 \mathrm{X}$ \\
\hline 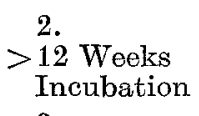 & 0 & $\begin{array}{l}255.0 \pm 43.4 \\
(12)\end{array}$ & $\begin{array}{l}407.3 \pm 60.7 \\
(\mathbf{1 3})\end{array}$ & $\begin{array}{l}557.7 \pm 57.0 \\
(\mathbf{1 3})\end{array}$ & $\begin{array}{l}691.5 \pm 79.9 \\
(13)\end{array}$ & $\mathrm{Y}=112.9+4.9 \mathrm{X}^{\mathrm{a}}$ \\
\hline $\begin{array}{l}3 . \\
>12 \text { Weeks } \\
\text { Incubation }\end{array}$ & 1 & $\underset{(7)}{251.4 \pm} 78.7$ & $\underset{(9)}{366.7 \pm 95.1}$ & $\begin{array}{l}464.4 \pm 101.0 \\
(9)\end{array}$ & $\begin{array}{l}588.9 \pm 132.6 \\
(9)\end{array}$ & $Y=140.3+3.7^{b a}$ \\
\hline $\begin{array}{l}4 . \\
>12 \text { Weeks } \\
\text { Incubation }\end{array}$ & 3 & $\begin{array}{l}320.7 \pm 104.7 \\
(6)\end{array}$ & $\begin{array}{l}491.5 \pm 53.5 \\
(6)\end{array}$ & $\begin{array}{l}514.8 \pm 74.4 \\
(5)\end{array}$ & $\begin{array}{l}616.5 \pm 95.4 \\
(6)\end{array}$ & $\mathrm{Y}=258.0+3.03^{\mathrm{ba}}$ \\
\hline $\begin{array}{l}5 . \\
>12 \text { Weeks } \\
\text { Incubation }\end{array}$ & 5 & $\begin{array}{l}213.9 \pm 73.4 \\
(9)\end{array}$ & $\underset{(9)}{318.9 \pm} 79.6$ & $\begin{array}{l}295.5 \pm 74.9 \\
(9)\end{array}$ & $\begin{array}{l}396.7 \pm 95.8 \\
(9)\end{array}$ & $Y=175.0+1.7^{b a}$ \\
\hline
\end{tabular}

a $p<0.01$ vs Group 1

b $p<0.01$ vs Group 2

that no insulin was secreted when these islets were incubated in the presence of exogenous insulin at the concentration of $1 \mathrm{mU} / \mathrm{ml}$ or more. On the other hand (Table 4), the islets of older obese mice, when incubated, secreted insulin at a significantly higher rate than either the islets of normal mice or those of younger obese mice and could not be suppressed completely by exogenous insulin, even at a concentration of $5 \mathrm{mU} / \mathrm{ml}$. Thus, it appears that the concentration of exogenous insulin necessary to inhibit the islets of obese mice increased as the animals became older and more hyperinsulinemic, eventually reaching values that were about 20 to 30 times higher than those found in the animals' own serum. A comparison of the results obtained with perifusion (Tables $2-4$ ) shows that although the islets of the obese mice produce greater amounts of insulin than those of their lean littermates, no significant differences were noted between their respective secretion rates. tissue $[44,45]$, increases the demand placed upon the pancreatic islets. In addition, hyperinsulinism may arise from a primary lesion of the islets themselves. These may either secrete an anti-insulin factor [46], be basically overactive $[39,42]$ or, as suggested in this paper, become insulin. resistant. The last hypothesis, if applicable to man, could offer a possible explanation for an often observed clinical phenomenon: the prolonged serum IRI response to oral glucose in obese individuals $[35,36,47]$. Thus, the abnormal islets would continue to secrete, even after the concentration of insulin in their extracellular fluid or in the B cells, reaches values at which normal islets are inhibited. Whatever this concentration may be, it must be many times higher than that found in the systemic circulation and, most likely, is determined, at least in part, by the intrinsic sensitivity of the islets, by their recent history of stimulation [48], by the existing concentration of glucose [3] and by the rate at which the newly 
synthesized hormone is washed away by the blood [49]. Indeed, pancreatic blood flow appears to increase when the secretion of insulin is stimulated and to decrease when the secretion of insulin is inhibited [50-52] or when the animal has received insulin injections [53]. Thus, the ultimate result of insular overwork would depend upon the degree and length of stimulation and

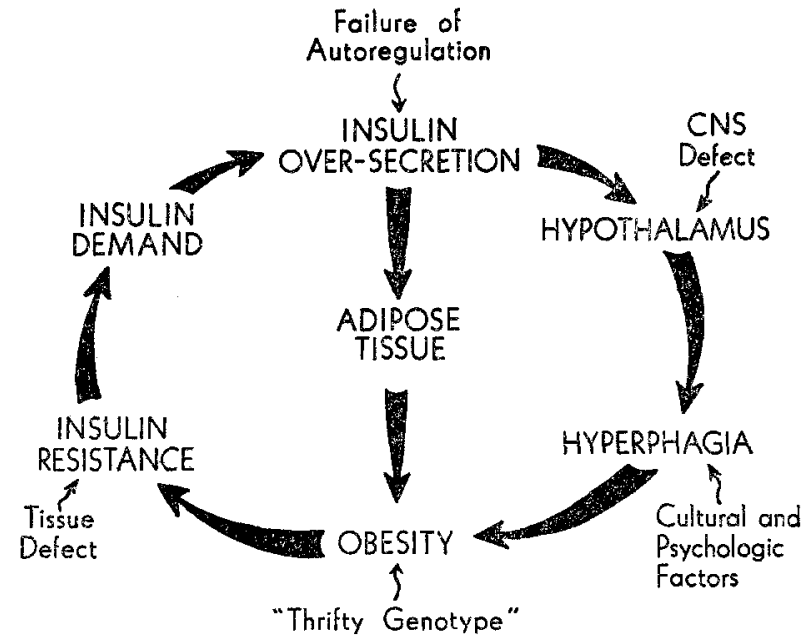

Fig. 2. Diagram illustrating the possible relationships between obesity and hyperinsulinism

upon the functional reserve of the $B$ cell: it could be hypertrophy, hyperplasia and continued hyperinsulinism if their resilience is high, as in some obese individuals and in the obob mice, or degeneration and failure, as in diabetic patients and in diabetic mice $[54,55]$. The mechanism whereby insulin inhibits its own secretion is not clear. The conditions of our experiments preclude that this action may be due to changes in the concentration of glucose. Fatigue of the islets or "intoxication" due to the accumulation of metabolites also can be excluded because it has been shown that isolated islets can secrete insulin for several hours $[26,56]$, because, in our own experiments, the islets of the obese mice continued to secrete without signs of suppression and, perhaps more convincingly, because no suppression of insulin secretion could be demonstrated when islets of either normal or obese animals were perifused with a constantly flowing buffer. The careful removal of exocrine tissue by microdissection and the stability of insulin in the incubation media provide persuasive evidence that proteolytic destruction of insulin did not introduce misleading artifacts. Thus, the most likely inhibitor appears to have been insulin itself.

In conclusion, we believe that our experiments have uncovered evidence for both propositions suggested in the introduction: that an autoregulation of insulin secretion exists in the islets of normal animals and that this mechanism is impaired in obob mice, especially when the obese-hyperglycemic syndrome is fully developed.
Acknowledgements. This work was aided by Grants No. AM06034 and No. RR05641 from the National Institute of Arthritis and Metabolic Diseases and by a grant from the Weight Watchers Foundation, Inc. and was done during Dr. Dunbar's tenure as Post-doctoral Trainee, NIH Diabetes Training Program No. AM05474.

\section{References}

1. Frerichs, H., Reich, U., Creutzfeldt, W.: Insulinsekretion in vitro. I. Hemmung der glucose-induzierten Insulinabgabe durch Insulin. Klin. Wschr. 43, 136$140(1965)$

2. Loubatières, A., Mariani, M.M., Chapal, J.: Inhibition de la sécrétion d'insuline par l'élévation de la teneur en insuline du milieu irriguant les cellules $\beta$ des ilots de Langerhans du pancréas. C. R. Acad. Sci $[D]$ (Paris) 266, 2245-2247 (1968)

3. Sodoyez, J.-C., Sodoyez-Goffaux, F., Foà, P.P.: Evidence for an insulin-induced inhibition of insulin release by isolated islets of Langerhans. Proc. Soc. exp. Biol. (N.Y.) 130, 568-571 (1969)

4. Sodoyez, J.-C., Sodoyez-Goffaux, F., Rosen, R.M., Foà, P.P.: Function of the pancreatic B-cells in hamsters bearing a transplantable islet cell tumor. Metabolism 18, 433-438 (1969)

5. Hahn, H.J., Michael, R.: Untersuchungen an Langerhansschen Inseln in vitro. V. Die Hemmung der glukoseinduzierten Insulinsecretion durch endogenes Insulin in vitro. Endocrinologie 57, 98-107 (1970)

6. Iversen, J., Miles, D.W.: Evidence for a feedback inhibition of insulin on insulin secretion in the isolated, perfused canine pancreas. Diabetes 20, 1-9 (1971)

7. Rappaport, A.M., Ohira, S., Coddling, J.A., Empey, G., Kalnins, A., Lin, B.J., Haist, R.E.: Effects on insulin output and on pancreatic blood flow of exogenous insulin infusion into an in situ isolated portion of the pancreas. Endocrinology 91, 168-176 (1972)

8. Foà, P.P.: The control of the secretory activity of the islets of Langerhans. Ciba Foundation Coll. Endocrin. 9, 55-71 (1956)

9. Sodoyez, J.-C., Sodoyez-Goffaux, F., Foà, P.P.: Pathogenesis of hypoglycemia in hamsters with a transplantable islet-cell tumor. J. Lab. clin. Med. 73, $432-438$ (1969)

10. Conn, J.W., Fajans, S.S.: Insulin depression and carbohydrate excitation of pancreatic islets of Langerhans. J. Lab. clin. Med. 32, 1411-1412 (1947)

11. Morgan, C.R., Carpenter, A.M., Lazarow, A.: Effect of insulin antibodies on pancreatic islet insulin and beta cell granule content. Anat. Rec. 153, 49-54 (1965)

12. Logothetopoulos, J., Davidson, J.K., Haist, R.E., Best, C.H.: Degranulation of beta cells and loss of pancreatic insulin after infusions of insulin antibody or glucose. Diabetes 14, 493-500 (1965)

13. Ziegler, M., Hahn, H.J., Klatt, D.: Influence of isolated insulin antibodies on the insulin secretion of the islets of Langerhans in vitro. Diabetologia 8, $148-149$ (1972)

14. Malaisse, W.J., Malaisse-Lagae, F., Wright, P.H.: Insulin secretion in vitro by islets from insulindeficient rats. Proc. Soc. exp. Biol. (N.Y.) 126, 474476 (1967)

15. Grodsky, G.M., Curry, D.L., Bennett, L.L., Rodrigo, J.J.: Faotors influencing different rates of insulin release in vitro. In Mechanism and Regulation of Insulin Secretion pp. 140-161. (Ed. R. Levine, E.F. Pfeiffer) Milano: Casa Ed. Il Ponte 1968 
16. Sando, H., Kanazawa, Y., Kuzuya, T.: Effect of bonito insulin on endogenous insulin secretion in dogs. Amer. J. Physiol. 218, 1357-1362 (1970)

17. Malaisse, W.J., Malaisse-Lagae, F., Lacy, P.E., Wright, P.H.: Insulin secretion by isolated islets in presence of glucose, insulin and anti-insulin serum. Proc. Soc. exp. Biol. (N.Y.) 124, 497-500 (1967)

18. Ohgawara, H., Suzuki, K., Kosaka, K.: Effect of prior infusion of exogenous bonito insulin on glucoseinduced insulin release in man. Endocrinol. jap. 20, 307-314 (1973)

19. Sodoyez, J.-C., Sodoyez-Goffaux, F.: Sensibilité à l'insuline des cellules $\mathrm{B}$ du pancréas de la souris obèse hyperglycémique. Annales Endocr. (Paris) 32, $199-202$ (1971)

20. Westman, S.: Metabolic studies of the obese-hyperglycaemic syndrome in mice pp. 827-832. In: Diabetes (Eds. Östman, J., Milner, R.D.G.) Amsterdam: Excerpta Med. Found. 1969

21. Loreti, L., Chen, S., Dunbar, J.C., Foà, P.P.: Effect of exogenous insulin on insulin secretion by isolated pancreatic islets of normal and obese-hyperglycemic (ob/ob) mice. Diabetes 21 (Suppl. 1), 344 (1972)

22. Dunbar, J.C., Foà, P.P.: Effect of insulin on islet metabolism in vitro. Fed. Proc. 32, 299 (1973)

23. Lacy, P.E., Kostianovsky, M.: Method for the isolation of intact islets of Langerhans from the rat pancreas. Diabetes 16, 35-39 (1967)

24. Hanks, J.H., Wallace, R.E.: Relation of oxygen and temperature in preservation of tissues by refrigeration Proc. Soc. exp. Biol. (N.Y.) 71. 196-200 (1949)

25. Hellerström, C.: A method for the microdissection of intact pancreatic islets of marnmals. Acta endocr. (Kbh.) 45, 122-132 (1964)

26. Dunbar, J.C., Foà, P.P.: An inhibitory effect of tolbutamide and glibenclamide (glyburide) on the pancreatic islets of normal animals. Diabetologia 10, 27-35 (1974)

27. Hales, C.N., Randle, P.J.: Immunoassay of insulin with insulin antibody precipitate. Biochem. J. 88, $137-146(1963)$

28. Greenwood, F.C., Hunter, W.M.: The preparation of 131I-labelled human growth hormone of high specific radioactivity. Biochem. J. 89, 114-123 (1963)

29. Yalow, R.S., Berson, S.A.: Immunoassay of endogenous plasma insulin in man. J. clin. Invest. 39, $1157-1175(1960)$

30. Snedecor, G.W., Cochran, W. G.: Statistical Methods. p. 135. Ames: Towa State University Press 1967

31. Lernmark, A.: Isolated mouse islets as a model for studying insulin release. Acta diabet. lat. 8, 649-679 (1971)

32. Nonaka, K., Foà, P.P.: A radioimmunoassay for glucagon. In: Laboratory Diagnosis of Endocrine Diseases pp. 378-384. (Eds. F. W. Sunderman, F.W. Sunderman, Jr.) St. Louis: Warren H. Green Inc. 1971

33. Wright, P.H., Malaisse, W.J., Reynolds, I.J.: Assay of partially neutralized guinea pig anti-insulin serum. Endocrinology 81, 226-234 (1967)

34. Benedetti, A., Simpson, R.G., Grodsky, G.M., Forsham, P.H.: Exaggerated insulin response to glucagon in simple obesity. Diabetes 16, 666-669 (1967)

35. Kreisberg, R. A., Boshell, B.M., Diplacido, J., Roddam, R. F.: Insulin secretion in obesity. New Engl. J. Med. 276, 314-319 (1967)

36. Bigelow-Sherman, J.D., Shima, K., Borden, E.K., Penhallegon, R., Foà, P.P.: The response of serum glucose, free fatty acid and immunoreactive insulin to oral glucose and intravenous tolbutamide in normal, potentially diabetic and diabetic subjects. Acta diabet. lat. 7, 68-92 (1970)

37. Shima, K., Foà, P.P.: Serum immunoreactive insulin and free fatty acid responses to oral glucose and to intravenous tolbutamide in normal, prediabetic and diabetic subjects. In: Tolbutamide. after Ton Xears, pp. 217-227. (Eds. W.J.H. Butterfield, W. van Westering) Amsterdam: Excerpta Medica, Found. 1967

38. Reaven, G.M., Olefsky, J., Farquhar, J.W.: Does hyperglyceamia or hyperinsulinaemia characterise the patient with chemical diabetes? Lancet 1972 I, $1247-1249$

39. Stauffacher, W., Orci, L., Cameron, D.P., Burr, I.M., Renold, A.E.: Spontaneous hyperglycemia and/or obesity in laboratory rodents. An example of the possible usefulness of animal disease models with both genetic and environmental components. Rec. Progr. Horm. Res. 26, 41-95 (1971)

40. Renold, A.E.: Spontaneous diabetes and/or obesity in laboratory rodents. Adv. Metab. Disord. 3, 49-84 (1968)

41. Genuth, S.M.: Hyperinsulinism in mice with genetically determined obesity. Endocrinology 84, 386-391 (1969)

42. Genuth, S.M., Przbyski, R.J., Rosenberg, D.M.: Insulin resistance in genetically obese, hyperglycemic mice. Endocrinology 88, 1230-1238 (1971)

43. Chlouverakis, C., Dade, E. F., Batt, R. A.I.: Glucose tolerance and time sequence of adiposity, hyperinsulinemia and hyperglycemia in obese-hyperglycomic mice (obob). Metabolism 19, 687-693 (1970)

44. Stern, J., Johnson, P.R., Greenwood, M.R.C., Zucker, L.M., Hirsch, J.: Insulin resistance and pancreatic insulin release in tho genetically obese Zucker rat. Proc. Soc. exp. Biol. (N.Y.) 139, 66-69 (1972)

45. Livingston, J.N., Cuatrecasas, P., Lockwood, D.H.: Insulin insensitivity of large fat cells. Science 177, $626-628(1972)$

46. Mahler, R.J., Szabo, O.: Amelioration of insulin resistance in obese mice. Amer. J. Physiol. 221, $980-983(1971)$

47. Jackson, W.P.U., Keller, P.: Glucose/insulin relationships in a population sample. Hormones $\mathbf{3}$, $361-374$ (1972)

48. Porte, D., Jr., Pupo, A.A.: Insulin responses to glucose: Evidence for a two pool system in man. J. clin. Invest. 48, 2309-2319 (1969)

49. Hellman, B., Lernmark, A. : Evidence for an inhibitor of insulin release in the pancreatic islets. Diabetologia 5, 22-24 (1969)

50. Rappaport, A.M., Davidson, J.K., Kawamura, T. Lin, B.J., Zelin, S., Henderson, J., Haist, R.E.: Quantitative determination of insulin output following an intravenous glucose tolerance test in the dog. Canad. J. Physiol. Pharmacol. 46, 373-381 (1968)

51. Rappaport, A.M., Kawamura, T., Davidson, J.K., Lin, B.J., Ohira, S., Zeigler, M., Coddling, J.A., Henderson, J., Haist, R.E.: Effects of hormones and of blood flow on insulin output of isolated pancreas in situ. Amer. J. Physiol. 221, 343-348 (1971)

52. Kanazawa, J., Kuzuya, T., Ide, T.: Insulin output via the pancreatic vein and plasma insulin response to glucose in dogs. Amer. J. Physiol. 215, 620-626 (1968) 
53. Semb, L.S., Aune, S.: The effect of glucose and insulin on pancreatic blood flow in the anesthetized pig. Scand. J. clin. Lab. Invest. 27, 105-111 (1971)

54. Seltzer, H.S., Fajans, S.S., Conn, J.W.: Spontaneous hypoglycemia as an early manifestation of diabetes mellitus. Diabetes 5, $437-442$ (1956)

55. Junod, A., Letarte, J., Lambert, A.E.: Studies in spiny mice (Acomys Cahirinus): Metabolic state and pancreatic insulin release in vitro. Horm. Metab. Res. 1, 45-52 (1969)
56. Hoshi, M., Shreeve, W.W.: Release and production of insulin by isolated, perifused rat pancreatic islets. Control by glucose. Diabetes 22, 16-24: (1973)

Dr. L. Loreti

Sinai Hospital of Detroit

Dept. of Research

6767 West Outer Drive

Detroit, Michigan 48235

USA. 